\title{
LEGITYMIZACJA PODATKU OD GIER - KIERUNKI POSZUKIWAŃ TEORETYCZNEJ KONCEPCJI
}

\section{WSTĘP}

Podatek od gier we współczesnej postaci obowiąuje w Polsce od 1992 r., a jego genezy można upatrywać w regale loteryjnym, którego tradycje sięgają XVIII w. ${ }^{1}$ Niemniej danina ta stosunkowo rzadko stanowi przedmiot zainteresowania przedstawicieli polskiej doktryny prawa podatkowego. Symptomatyczny jest również fakt, że zagadnieniom opodatkowania gier hazardowych poświęca się wyjątkowo mało uwagi w trakcie procesów projektowania i uchwalania przepisów dotyczących reglamentacji hazardu. Świadczy o tym treść dostępnych materiałów legislacyjnych, w tym uzasadnień projektów ustaw, w których kwestie opodatkowania bądź są traktowane zdawkowo, bądź całkowicie pomijane. W szczególności brakuje informacji o tym, jakie założenia legły u podstaw wprowadzanych modyfikacji i jakie rezultaty, poza oczywistym efektem fiskalnym, zamierzano osiąnąć. Jednym z zagadnień, któremu nie poświęcono dotychczas odrębnego opracowania, jest problematyka teorii dotyczących opodatkowania działalności polegającej na urządzaniu gier hazardowych. W przeciwieństwie do powszechnego podatku dochodowego, podatków obciążających nieodpłatne nabycie majątku czy akcyz, w odniesieniu do których już w okresie międzywojennym szeroko prezentowano różnorodne koncepcje uzasadniające bądź negujące sens ich istnienia, podatki obciążające profesjonalna działalność w sferze hazardu pozostawały poza głównym nurtem badań nauki skarbowości oraz prawa finansowego. Próby poszukiwania uzasadnienia podatków od gier w świetle teorii ekonomicznych niezmiernie rzadko podejmowane są również w literaturze zachodniej. Przyczyn takiego stanu rzeczy należy upatrywać przede wszystkim w uwarunkowanym kulturowo sposobie percepcji zjawiska hazardu, czego wyrazem jest między innymi dominujaca do połowy XIX w. forma czerpania dochodów z działalności hazardowej w formie przywilejów (monopoli) skarbowych.

Celem niniejszego artykułu jest identyfikacja teorii ekonomicznych, w świetle których upatruje się uzasadnienia podatków od gier hazardowych przyjmujacych postać selektywnych podatków obrotowych oraz konfrontacja założeń tych teorii ze specyfiką zjawiska, jakim jest hazard. Z uwagi na to, że problematyka uzasadnienia funkcjonowania tego rodzaju danin może podle-

1 Szerzej Ofiarski (2013): 141-157; Duda-Hyz (2017): 89-109. 
gać analizie w wielu aspektach, realizacja zakreślonego w powyższy sposób zadania badawczego wymagała przyjęcia wstępnych założeń.

Po pierwsze, należy zauważyć, że identyfikacja i analiza argumentów uzasadniających opodatkowanie działalności hazardowej w formie selektywnych podatków obrotowych może być przeprowadzana w różnych płaszczyznach. W płaszczyźnie ekonomiczno-społecznej historycznie dominuje postrzeganie sektora hazardowego jako bardzo wydajnego fiskalnie, który tym samym winien podlegać opodatkowaniu w sposób bardziej dotkliwy². Wskazuje się również, że podatki od gier mogą stanowić instrument zapobiegania zaburzeniom uprawiania hazardu ${ }^{3}$. W płaszczyźnie moralnej podatki od gier są traktowane jako formy „kary” lub „odkupienia” za czerpanie korzyści z aktywności uznawanej za bezproduktywną i etycznie naganna ${ }^{4}$. W płaszczyźnie techniki podatkowej uzasadnienia formy selektywnych podatków obrotowych można upatrywać między innymi w trudnościach, jakie w przypadku usług hazardowych rodzi ustalenie podstawy opodatkowania na potrzeby podatku od wartości dodanej czy konieczność zachowania neutralności tego podatku ${ }^{5}$. Z uwagi na rozmiar artykułu zakres analizy przeprowadzonej na potrzeby niniejszego opracowania został ograniczony wyłącznie do tych argumentów, które wynikaja z założeń teorii ekonomicznych rozumianych jako kolekcje formalnych modeli zinterpretowanych w języku ekonomii ${ }^{6}$. Po drugie, kwestia, która nie została poruszona w niniejszym artykule, a która niewątpliwie zasługuje na naukową refleksję, jest analiza wpływu rzeczonych teorii na tworzenie przepisów normujących podatki od gier. W szczególności poza zakresem prezentowanych treści pozostaje problem oceny, jakie założenia teoretyczne legły u podstaw konstrukcji funkcjonującego w Polsce podatku od gier i czy zasadna jest zmiana obecnego modelu opodatkowania.

Realizując wskazany cel badawczy, dokonano przeglądu literatury polsko-, anglo- i niemieckojęzycznej na temat podatków od gier. Przeszukane zostały elektroniczne bazy danych: Springer Link, SocINEX, Legal Source, Academic Search Ultimate, Business Source Ultimate, eBook Collection (EBSCOhost) oraz MasterFILE Premier za pomocą słów kluczowych „gambling tax”, „Glücksspiel Steuern” i „Besteuerung von Glücksspielen”. Wykorzystano także przeglądarkę Google Scholar. Ze względu na to, że hazard należy do kategorii zjawisk, które w erze globalizacji rodza podobne, jeśli nie takie same, problemy społeczne, analizując specyfikę tego zjawiska w kontekście zidentyfikowanych teorii ekonomicznych wykorzystano opracowania z zakresu gambling studies dotyczace zarówno rynku europejskiego, jak i amerykańskiego, a także azjatyckiego.

${ }^{2}$ Szerzej Adams, Fiedler (2018); Gu, Li (2008): 2.

${ }^{3}$ Szerzej Brüggemann (2015): 136-140.

${ }^{4} \mathrm{~W}$ doktrynie francuskiej używa się określenia „odkupieńcze opodatkowanie” (fiscalité rédemptrice) Markus (2016). W literaturze niemieckiej (Kahle, Willer 2019: 142) wskazuje się na opodatkowanie „instynktu gry” (Spieltrib). W doktrynie amerykańskiej (Meich 2008: 460) podatki od gier nazwane sa podatkami od przywileju (privilege taxes). Postrzega się je również (Harvey, Swayze, Walls 2004: 407) jako element „moralnej perswazji” (moral suasion).

${ }^{5}$ Szerzej Annacondia, Alonso (2017): 379; Vieweg (2009): 13-21.

${ }^{6}$ Definicja teorii ekonomicznej przyjęta za: Malawski (2016): 175. 


\section{TEORIA OPTYMALNEGO OPODATKOWANIA}

Pierwszą koncepcja, w świetle której w płaszczyźnie ekonomiczno-społecznej poszukuje się uzasadnienia podatków od gier, jest teoria optymalnego opodatkowania ${ }^{7}$. Teoria ta zakłada maksymalizację dobrobytu społecznego przy danych wpływach podatkowych $\mathrm{w}$ drodze minimalizacji kosztów egzekucji fiskalnej, tj. dodatkowych strat $\mathrm{w}$ dobrobycie, które reprezentują koszty dostosowań będacce skutkiem zmiany relacji cen w wyniku opodatkowania i sa wyrazem efektów substytucyjnych ${ }^{8}$. W zakresie opodatkowania konsumpcji wszelkie próby poszukiwań optymalnych rozwiązań nawiązuja bezpośrednio lub pośrednio do metodologicznego wzorca zastosowanego przez Franka Ramseya, który wskazał, że gdy chodzi o niewielki wzrost przychodu podatkowego, podatki powinny powodować równą i proporcjonalną redukcję konsumpcji każdego dobra. Zgodnie z klasyczna regułą Ramseya optymalny jest zatem taki system podatkowy, w którym taka sama relatywna zmiana wszystkich kwot podatkowych wywołuje identyczna, relatywną zmianę skompensowanego popytu na wszystkie dobra ${ }^{9}$. Przyjmując dodatkowe założenie, że popyt na każdy towar jest niezależny od cen innych towarów, Ramsey sformułował regułę odwrotnej proporcjonalności stawek podatkowych względem elastyczności. Ekonomiczny sens owej reguły można sprowadzić do twierdzenia, że towary, na które popyt jest najmniej elastyczny cenowo, powinny być opodatkowane najwyżej, ponieważ dobra o niskiej elastyczności popytu wywołują wskutek opodatkowania mniejsze efekty substytucyjne niż dobra charakteryzujące się wyższą elastycznością ${ }^{10}$.

W świetle powyższej teorii bardziej dotkliwe opodatkowanie działalności gospodarczej polegającej na świadczeniu usług hazardowych uzasadnia się tym, że popyt na tego rodzaju usługi, podobnie jak popyt na takie towary, jak: napoje alkoholowe, wyroby tytoniowe czy paliwa, wykazuje niską elastyczność cenowa ${ }^{11}$. Należy jednak zwrócić uwagę, że wyniki przeprowadzonych w ostatnich latach badań nie potwierdzaja jednoznacznie tezy, jakoby podwyższenie cen usług hazardowych w każdych okolicznościach w niewielkim stopniu wpływało na ich popyt. Po pierwsze, w opracowaniach z zakresu nauk ekonomicznych wskazuje się, że w przypadku usług hazardowych poziom elastyczności cenowej popytu jest zróżnicowany w odniesieniu do poszczególnych form aktywności hazardowej. Z raportu przygotowanego na zlecenie brytyjskich organów skarbowych wynika, że największą elastyczność cenową wykazywał popyt na gry hazardowe oferowane zdalnie, loterie oraz tzw. zdrapki, popyt na zakłady i bingo urządzane $\mathrm{w}$ formach naziemnych był proporcjonalnie elastyczny, natomiast mniejszą wrażliwość na zmianę cen odnotowano w przy-

\footnotetext{
7 Clotfelter (2005): 102-105; Meich (2008): 461-462.

${ }^{8}$ Grądalski (2006): 104. Szerzej Heady (2007): 41-80.

9 Grądalski (2006): 131-134.

10 Szerzej Grądalski (2006): 139-141; McGee (2004): 232-233 oraz powołana tam literatura.

11 McCarten, Stotsky (1995): 100-101.
} 
padku totalizatorów, gier na automatach oraz zdalnych zakładów ${ }^{12}$. Wyniki badań dotyczących powyższego zagadnienia świadczą również o tym, że popyt na gry oferowane w kasynach jest mniej elastyczny cenowo niż popyt na gry loteryjne oraz zakłady konne ${ }^{13}$. Bez wątpienia istotnym czynnikiem zwiększającym poziom elastyczności cenowej popytu na usługi hazardowe jest także możliwość ich świadczenia przez sieć Internet ${ }^{14}$.

Po drugie, należy mieć na uwadze fakt, iż elastyczność cenowa popytu na gry hazardowe może być oceniana różnie, w zależności od przyjętej perspektywy czasowej. Powyższa supozycja znajduje potwierdzenie między innymi w wynikach badań dotyczących gier oferowanych w amerykańskich kasynach, z których wynika, że w krótkim horyzoncie czasowym popyt na tego rodzaju usługi był nieelastyczny, natomiast w dłuższej perspektywie charakteryzował się proporcjonalną elastycznością ${ }^{15}$. Analizy poświęcone grom na automatach dostępnych w USA na statkach rzecznych i torach wyścigowych wykazały z kolei, że elastyczność cenowa popytu zmniejszała się wraz z upływem czasu ${ }^{16}$.

Po trzecie, poziom elastyczności cenowej popytu na gry tego samego rodzaju może być zróżnicowany w zależności od tego, jaka jest struktura rynku oraz w jakim zakresie operatorzy mają możliwość przerzucania ciężaru podatków od gier na graczy. W tym aspekcie na uwagę zasługują badania dotyczące kasyn funkcjonujacych w Macao i Las Vegas. Wynika z nich bowiem, że elastyczność popytu jest mniejsza w sytuacji, gdy gry są oferowane na rynkach oligopolistycznych, a zasadniczą część klientów kasyn stanowią turyści. Turyści, w przeciwieństwie do miejscowych, regularnych graczy zwracaja bowiem mniejszą uwagę na to, jaka jest stopa zwrotu poszczególnych gier i ile wynosi przewaga kasyna ${ }^{17}$.

Wskazując na wątpliwości, jakie może rodzić próba poszukiwania uzasadnienia podatków od gier w świetle teorii optymalnego opodatkowania, wypada również zaznaczyć, że z określeniem poziomu elastyczności cenowej popytu na gry hazardowe wiąże się szereg problemów metodologicznych. Wynikają one w głównej mierze z braku wyczerpujących danych na temat cen, jakie są stosowane przez operatorów gier, co jest szczególnie dostrzegalne w przypadku gier kasynowych ${ }^{18}$. W przeciwieństwie do usług, których cena jest z góry ustalona, na cenę gier hazardowych wpływają bowiem takie czynniki, jak: reguły danej gry, stopa zwrotu w grze ${ }^{19}$, okres czasu spędzony na grze, a w przypadku gier zaliczanych do tzw. gier szczęścia i umiejętności - także doświadczenie

${ }^{12}$ Szerzej: Frontier Economics, The UK betting and gaming market: estimating price elasticities of demand and understanding the use of promotions. A report prepared for HM Revenue and Customs, June 2014, <https://www.gov.uk/government/uploads/system/uploads/attachment.../report313.pdf $>$ : $37-53$.

${ }^{13}$ Szerzej Gallet (2015): 12-22 oraz powoływana tam literatura.

${ }^{14}$ Diemer, Rodenberg (2013): 138.

${ }^{15}$ Szerzej Landers (2008): 1-15.

${ }^{16}$ Szerzej Thalheimer, Ali (2003): 907-918.

${ }^{17}$ Szerzej Gu, Tam (2014): 53-68; Gu, Li (2011): 201-211.

${ }^{18} \mathrm{~W}$ odniesieniu do gier kasynowych kontrowersje rodzi sama koncepcja ceny gry. Szerzej Nichols, Tosun (2013): 38-46; Forest (2012): 37-41; Siu (2011): 267-277.

19 Ang. payoff. 
i umiejętności graczy ${ }^{20}$. Nadto należy podkreślić, że w odniesieniu do gier hazardowych zauważalny jest efekt substytucyjny polegający na zastępowaniu jednych rodzajów gier drugimi (np. gier loteryjnych kasynowymi, czy totalizatorów wideoloteriami) ${ }^{21}$.

\section{TEORIA KOREKCYJNEGO PODATKU EKOLOGICZNEGO}

Drugą teorią ekonomiczną, w świetle której poszukuje się uzasadnienia podatków od gier, jest koncepcja korekcyjnego podatku ekologicznego, której teoretyczne podstawy sformułował angielski ekonomista Arthur C. Pigou. U podstaw powyższej teorii leży założenie o konieczności rozróżnienia społecznych kosztów aktywności gospodarczej i indywidualnych kosztów przedsiębiorstwa, rejestrowanych w rachunku zysków i strat. Różnica pomiędzy kosztami społecznymi a indywidualnymi to tzw. efekt zewnętrzny (np. w postaci zanieczyszczenia środowiska), który jest traktowany jako koszt zastosowania przez producenta czynnika wytwórczego, jakim jest środowisko. Koszt ten jest przerzucany na społeczność konsumentów, czyli podlega tzw. eksternalizacji, ograniczając konsumentom możliwość realizacji potencjalnego dobrobytu ${ }^{22}$. Koncepcja podatku Pigou stanowi zatem próbę harmonizacji indywidualnych celów podmiotów gospodarczych, czyli maksymalizacji zysku, z celami ogólnospołecznymi rozumianymi jako maksymalizacja dobrobytu. Zadanie to ma być zrealizowane przez internalizację kosztów wspomnianych efektów zewnętrznych, tj. przypisanie ich przedsiębiorcy, który je wygenerował ${ }^{23}$. Na przestrzeni lat idea podatku Pigou podlegała rozwinięciu poprzez tworzenie różnych modeli teoretycznych tego typu konstrukcji, które zaczęto odnosić do efektów zewnętrznych związanych nie tylko z zanieczyszczeniami środowiska, lecz także z paleniem papierosów, spożywaniem alkoholu, konsumpcją niezdrowej żywności, obrotem bronia, a nawet usługami finansowymi. W świetle powyższych teorii konsumenci niezdrowych produktów czy oferujący i korzystajacy z ryzykownych usług powinni ponosić ciężar podatku, który odzwierciedla koszty, jakie w związku z ich zachowaniami zmuszone jest ponosić całe społeczeństwo ${ }^{24}$. Warto także zwrócić uwagę, że wyższe opodatkowanie aktywności postrzeganej jako bezproduktywna, zbytkowa lub szkodliwa przynosi dodatkowe dochody, w związku z czym pozwala na obniżenie innych podatków. Tym samym może przyczynić się do zrównoważenia zniekształcających efektów, jakie wywołuja pozostałe daniny (np. podatki dochodowe oddziałujace negatywnie na motywację do pracy). Zjawisko to określa się mianem „podwójnej

\footnotetext{
${ }^{20}$ Szerzej Hannum (2013): 376-378.

${ }^{21}$ Szerzej Marfels (1997): 333-340; Forrest, Gulley, Simmons (2010): 26-38; Walker, Hodges (2018) oraz powoływana tam literatura.

${ }^{22}$ Szerzej Gradalaski (2006): 233-237 oraz powoływana tam literatura.

${ }^{23}$ Mazurek-Chwiejczak (2014): 60.

${ }^{24}$ Szerzej Chaloupka, Wakefield (2001): 61-63; Cummings (2010): 286-290; Shackelford, Shaviro, Slemrod (2012): 160-164.
} 
dywidendy" i podnosi, że podatki obciążające niepożądaną konsumpcję z jednej strony zmniejszają rozmiary efektów zewnętrznych, a z drugiej - wyrównują zniekształcenia występujące w innych sferach gospodarki, zwiększając efektywność ekonomiczną systemu podatkowego ${ }^{25}$.

W literaturze przedmiotu koncepcję podatku korekcyjnego odnosi się rów nież do działalności polegającej na urządzaniu gier hazardowych, wskazując, że podatki od gier powinny służyć złagodzeniu społecznych kosztów hazardu, jeżeli koszty te nie moga być internalizowane poprzez mechanizmy rynkowe lub równoważone w drodze innych rozwiązań, np. podwyższonych stawek ubezpieczeniowych. Wysokość podatków od gier winna być zatem ustalona w taki sposób, aby odzwierciedlać całokształt efektów zewnętrznych, jakie wiążą się z hazardem. W odniesieniu do naziemnych ośrodków gier zwraca się przy tym uwagę na konieczność uwzględnienia zarówno kosztów ponoszonych przez lokalne społeczności, jak i kosztów podlegających swoistemu „eksportowi” w warunkach tzw. turystyki hazardowej ${ }^{26}$. Celem korekcyjnych podatków od gier jest zatem zmuszenie podmiotów działających na rynku hazardowym do internalizacji kosztów ich działalności, natomiast za ekonomicznie uzasadnione uznaje się tylko takie usługi hazardowe, z których korzyści przewyższają zarówno koszty ich świadczenia, jak i wysokość podatku korekcyjnego ${ }^{27}$.

Jak już zaznaczono, negatywne efekty zewnętrzne odnoszą się do sytuacji, w których część kosztów związanych z transakcją nie dotyczy bezpośrednio jej stron, ale osób trzecich, w związku z czym nie jest uwzględniona w cenie, która z punktu widzenia całego społeczeństwa może być przez to za niska. Skonstruowanie podatku od gier, który spełniałby funkcję korekcyjna, wymaga zatem oszacowania wielkości wspomnianych efektów zewnętrznych, a tym samym i kosztów społecznych hazardu, co stanowi kwestię niezwykle złożoną i kontrowersyjna. W naukach ekonomicznych podejmowano próby wartościowego określenia kosztów społecznych, jakie wiążą się ze zjawiskiem uzależnień od gier hazardowych ${ }^{28}$. Oszacowanie całokształtu efektów zewnętrznych hazardu rodzi jednak szereg problemów metodologicznych, które dotyczą trzech zasadniczych kwestii.

Po pierwsze, brak zgodności co do samej definicji kosztów społecznych hazardu oraz efektów zewnętrznych działalności hazardowej29. Abstrahujac od rozbieżności w tym zakresie, warto zwrócić uwagę, że w literaturze przedmiotu do kosztów społecznych hazardu zalicza się najczęściej koszty finansowe wynikające z bankructw, a także koszty związane z: produktywnością i praca (obniżona wydajność w pracy, zmniejszenie siły roboczej będące skutkiem absencji, samobójstw oraz braku szans na zatrudnienie z uwagi na niewystarczające kwalifikacje), ochroną zdrowia (opieka psychologiczna i medyczna nad

25 Philander (2013): 20.

${ }^{26} \mathrm{Li}, \mathrm{Gu}, \mathrm{Wu}$ (2015): 597-598.

27 Philander (2013): 20; Frey (1992): 355; Barth (2013): 3.

28 Szerzej Thompson, Gazel, Rickman (1997): 87-89; Kindt (1998): 91.

29 Szerzej Walker (2007a): 85-111; Collins, Lapsley (2003): 123-147 oraz powoływana tam literatura. 
osobami uzależnionymi od hazardu, ich rodzinami oraz ofiarami przestępstw związanych z hazardem), walką z przestępczościa, działaniami prewencyjnymi oraz regulacjami prawnymi i badaniami naukowymi dotyczacymi zjawiska hazardu ${ }^{30}$.

Po drugie, w przypadku kosztów społecznych i efektów zewnętrznych wynikających z aktywności hazardowej szereg problemów metodologicznych rodzi kwestia określenia ich rozmiarów. Trudności dotyczą zarówno oszacowania wydatków oraz strat finansowych ponoszonych przez graczy ${ }^{31}$, jak i wysokości środków publicznych wydatkowanych m.in. na przeciwdziałania i zwalczenie przestępstw związanych z hazardem czy opiekę medyczną nad osobami, u których zdiagnozowano zaburzenia w zakresie uprawiania hazardu. Należy bowiem zauważyć, że gracze przejawiający problematyczne zachowania niejednokrotnie cierpią także z powodu innych zaburzeń, np. uzależnienia od alkoholu, narkotyków, czy depresji ${ }^{32}$. Co więcej, do kosztów społecznych hazardu zalicza się również takie koszty, które nie podlegają bezpośredniej wycenie rynkowej, np. stres i cierpienie przeżywane przez hazardzistów i ich rodziny, samobójstwa, pogorszenie jakości życia czy skutki w dziedzinie kultury ${ }^{33}$.

Po trzecie, skoro efekty zewnętrzne hazardu stanowią pochodną problematycznych zachowań graczy, wyższe obciążenie podatkowe powinno być stosowane w odniesieniu do tych form aktywności hazardowej, z którymi wiąże się większe ryzyko pojawienia się takich zachowań ${ }^{34}$. Niestety, mimo że pewne formy aktywności hazardowej powszechnie są uważane za niosace znaczne ryzyko pojawienia się zaburzeń uprawiania hazardu ${ }^{35}$, wyniki badań z zakresu nauk społecznych nie pozwalają na jednoznaczne określenie potencjału uzależniającego oraz skali innych zagrożeń (np. przestępczościa) związanych z poszczególnymi kategoriami gier hazardowych ${ }^{36}$. Powyższe względy przesądzają o tym, że koncepcja korekcyjnego podatku od gier, choć bardzo atrakcyjna w płaszczyźnie teoretycznej, rodzi poważne problemy aplikacyjne w praktyce gospodarczej ${ }^{37}$. Wypada także zwrócić uwagę, że w przypadku niektórych form aktywności hazardowej istotna część efektów zewnętrznych nie jest ponoszona przez lokalna gospodarkę, co pozwala danemu związkowi publicznoprawnemu na osiagnięcie efektu korekcyjnego przy niższej wysokości podatku od gier. Taka sytuacja może zachodzić zarówno w przypadku

30 Szerzej Collins, Lapsley (2003): 141; Winkler, Bejdura, Csémy, Weissová (2016).

31 Szerzej Walker (2013): 122.

32 Szerzej Walker (2008): 20-26; Eadington (2003): 185-211; Walker (2003): 150-181; Walker (2007): 609-646 oraz powoływana tam literatura.

${ }^{33}$ Collins, Lapsley (2003): 141. Zob. także Costes, Massin, Etiemble (2014): 1-5.

${ }^{34}$ Philander (2013): 21.

35 Szerzej Breen, Zimmerman (2002): 32; Thomas, Sullivan, Allen (2009): 97-107 oraz powoływana tam literatura.

36 Szerzej Mizerski, Jolley (2001): 276-283; Dowling, Smith, Thomas (2005): 33-45.

$37 \mathrm{~W}$ opracowaniach z zakresu nauk ekonomicznych podejmowano próby określenia wysokości korekcyjnego podatku od gier, wskazując, że jeżeli koszty społeczne funkcjonowania kasyn mieszczą się w przedziale od 180 do 289 USD, podatek służący skorygowaniu negatywnych efektów zewnętrznych generowanych przez kasyna winien kształtować się na poziomie od $45 \%$ do $70 \%$ dochodów z tytułu urządzania gier brutto. Grinols (2004): 183. 
naziemnych usług hazardowych w formie centrów gier kasynowych, których odbiorcami są głównie turyści z innych państw, jak i światowych centrów gier oferowanych online ${ }^{38}$.

\section{TEORIE EKONOMII BEHAWIORALNEJ}

Uzasadnienia podatków od gier upatruje się również w teoriach ekonomii behawioralnej ${ }^{39}$ oraz programie polityki interwencjonistycznej określanym mianem średniego paternalizmu. Przyjmuje się bowiem założenie, że wprowadzenie tego rodzaju danin może przynieść skutek w postaci poprawy dobrobytu jednostki poprzez eliminację zniekształceń poznawczych związanych z podejmowaniem decyzji ${ }^{40}$. Ekonomia behawioralna jest dziedziną wiedzy łącząca dokonania ekonomii i psychologii, u której podstaw legło zakwestionowanie racjonalności jednostki oraz podważenie założenia o znajomości mechanizmów i danych rynkowych niezbędnych do podjęcia decyzji ${ }^{41}$. Przedstawiciele tej dziedziny wskazują na pewne systematyczne błędy poznawcze popełniane przez jednostki w procesie podejmowania decyzji ekonomicznych. Jedna z zaobserwowanych w tym zakresie prawidłowości jest tzw. dyskontowanie hiperboliczne $^{42}$, które naświetla zjawisko odwracania się preferencji, ukazujące wpływ krótkowzroczności, niecierpliwości oraz braku samokontroli i siły woli na dokonywane wybory ${ }^{43}$. Ponieważ jednostki wykazują większą wrażliwość na bliższą przyszłość, tj. skłonność do preferowania celów krótkookresowych i szybkich nagród oraz niedoceniania przyszłości, trudno jest im zerwać ze szkodliwymi nawykami. Natychmiastowa przyjemność związana z jedzeniem, używkami czy hazardem przewyższa bowiem przyszłe korzyści wynikające ze zdrowego stylu życia czy oszczędzania. Przyjęcie założenia, że jednostki nie sa zdolne do podejmowania racjonalnych decyzji służących maksymalizacji ich dobrobytu, prowadzi z kolei do wniosku, że zasadne jest wprowadzanie podatków obciążających szkodliwą konsumpcję, które mają skłonić potencjalnych konsumentów do podejmowania bardziej korzystnych dla nich decyzji. $\mathrm{Na}$ gruncie teorii ekonomii behawioralnej upatruje się zatem uzasadnienia tych selektywnych podatków obrotowych, których przedmiot opodatkowania stanowi obrót towarami i usługami powszechnie uznawanymi za stwarzające zagrożenie dla ich konsumentów, a tym samym wywołujące negatywne skutki społeczne. Wypada także zaznaczyć, że choć podatki tego typu tradycyjnie określa się mianem „podatków od grzechu”44, we współczesnym piśmiennic-

38 Philander, Walker (2012): 15.

${ }^{39} \mathrm{Na}$ gruncie ekonomii behawioralnej opracowano szereg koncepcji, w świetle których może być również analizowane zjawisko hazardu. Szerzej zob. Walker, Mandell (2018).

40 Ang. medium paternalism. Szerzej Holmes Perkins (2014): 157; Kirchgässner (2015).

41 Szerzej Zalega (2015): 7-23; Godłów-Legiędź (2013): 24-39.

42 Ang. hyperbolic discounting.

43 Swacha-Lech (2012): 797-798. Szerzej Whitman, Rizzo (2007): 418-420.

${ }_{44}$ Ang. sin taxes. 
twie ów grzech nie jest ujmowany w kategoriach religijnych czy etycznych lecz operacyjnych. Oznacza bowiem zachowania destrukcyjne, rodzace zagrożenie uzależnieniami oraz społecznie niepożądane ${ }^{45}$.

W teoriach ekonomii behawioralnej poszukuje się najczęściej uzasadnienia podatków obciążających konsumpcję alkoholu, wyrobów tytoniowych i paliw, a w ostatnich latach również niezdrowej żywności ${ }^{46}$. Uwarunkowany rozwojem nowoczesnych technologii intensywny proces legalizacji, legitymizacji i instytucjonalizacji hazardu przyczynił się do tego, że funkcję instrumentów kształtujacych ludzkie zachowania przypisuje się również podatkom od gier. Oczywiście wynika to z przekonania, że konsumpcja usług hazardowych jest bezproduktywna, zbytkowa i szkodliwa ${ }^{47}$. Warto podkreślić, że w odniesieniu do tej kategorii podatków również używa się określeń „podatki od grzechu” lub „podatki od występków”48, co jednoznacznie wskazuje na sposób postrzegania zjawiska społecznego jakim jest hazard.

Koncepcja podatków wpływających na zwiększenie samokontroli, a tym samym ograniczenie szkodliwej konsumpcji, nie jest pozbawiona wad. Niewątpliwie jej główną słabością jest supozycja jakoby jednostki co do zasady nie były w stanie dostrzegać i uświadamiać sobie, co stanowi ich własne dobro, podczas gdy przeważająca liczba dorosłych osób w większości sytuacji dokonuje dla siebie lepszych wyborów niż wynikające z woli organów władzy publicznej czy osób trzecich ${ }^{49}$. Zwraca się również uwagę, że paternalistyczna interwencja stwarza zagrożenia moralne i poznawcze ${ }^{50}$, ograniczając możliwość korygowania własnych błędów i zwiększając ryzyko ich popełniania w przyszłości ${ }^{51}$. Wskazując na opodatkowanie działalności polegającej na urządzaniu gier hazardowych, należy nadto zauważyć, że jedynie niewielka liczba graczy przejawia problematyczne zachowania. Dla większości uczestników gier udział w tego rodzaju przedsięwzięciach stanowi świadomie wybierana i kontrolowaną formę rozrywki, nie rodząc przy tym negatywnych skutków społecznych $^{52}$. Dotkliwe opodatkowanie usług hazardowych wywołuje zatem efekt również w odniesieniu do tych osób, których decyzje nie wynikają z braku samokontroli.

Idea opodatkowania konsumpcji w celu poprawy dobrobytu jednostek rodzi także szereg problemów aplikacyjnych w praktyce. Ponieważ różne osoby w różny sposób reagują na podwyższenie cen danych towarów i usług, poza oczekiwanym rezultatem polegającym na zmniejszeniu skali niepożądanej konsumpcji, można uzyskać efekt w postaci zaspokajania potrzeb na nielegalnych rynkach, zastępowania jednych form szkodliwej konsumpcji innymi czy

45 Szerzej Lorenzi (2004): 60; (2006): 67.

46 Szerzej Tresch (2008): 480; Congdon, Kling, Mullainathan (2011): 60-62.

${ }_{47}$ Szerzej Thompson (2010): 18; Vermeed, van der Ploeg, Timmer (2009): 210; Clotfelter (2005): 85; Lorenzi (2010): 328-332; Harvey, Swayze, Walls (2004): 407-412.

${ }^{48}$ Ang. taxes on vices. Szerzej McGee (2004): 233; Hoffer, Shughart II, Thomas (2014): 49.

49 Landes (2015): 109; O’Donoghue, Rabin (2006): 1841.

50 Ang. moral and cognitive hazards.

51 Szerzej Whitman, Rizzo (2007): 430-431.

52 Clarke (2008): 33. 
też zadłużenia się osób, które nie są w stanie podejmować racjonalnych decy$z_{j i}{ }^{53}$. Problem ten jest szczególnie istotny w kontekście opodatkowania gier hazardowych urządzanych online. Transgraniczny charakter Internetu przesądza bowiem o tym, że gracze mogą stosunkowo łatwo skorzystać z oferty operatorów działających bez zezwoleń wydanych przez władze danego państwa, a tym samym uprawiać hazard w warunkach, które nie zapewniaja pełnej ochrony ich praw. Skuteczność instrumentów podatkowych, które w założeniu mają skłonić konsumentów do podejmowania bardziej korzystnych dla nich decyzji, zależy nadto od tego, w jakim zakresie osoby te biorą pod uwagę koszt danego towaru lub usługi po ich opodatkowaniu ${ }^{54}$. Z przeprowadzonych badań wynika, że zdolność oceny ekonomicznych skutków uczestnictwa w grze jest uzależniona między innymi od poziomu wykształcenia graczy ${ }^{55}$. Jak już zaznaczono, w przypadku większości gier hazardowych gracze nie sa jednak świadomi marży stosowanej przez operatorów, a tym bardziej nie mają możliwości oceny, w jakim zakresie wpływa na nią wysokość podatku od gier. Oznacza to, że potencjalni nabywcy usług hazardowych nie sa w stanie ocenić całkowitej ceny danej gry. Zamykając uwagi na temat problemów aplikacyjnych, jakie w kontekście podatków od gier rodzą teorie ekonomii behawioralnej, warto także zaznaczyć, że ze względu na regresywny charakter selektywnych podatków obrotowych koszty podwyższenia ciężaru podatkowego rzeczonych danin co do zasady w większym stopniu ponoszą osoby mniej zamożne ${ }^{56}$. W konsekwencji w niektórych sytuacjach osoby te moga nawet wydatkować środki na gry hazardowe kosztem zaspokajania podstawowych potrzeb ${ }^{57}$.

\section{UWAGI KOŃCOWE}

Przeprowadzona analiza prowadzi do konkluzji, że uzasadnienia podatków obciążających prowadzenie działalności polegającej na urządzaniu gier hazardowych poszukuje się $\mathrm{w}$ teorii optymalnego opodatkowania, teorii korekcyjnego podatku ekologicznego oraz teoriach ekonomii behawioralnej. Jest rzeczą oczywista, że powyższe teorie uzasadniają funkcjonowanie także innych danin, w głównej mierze selektywnych podatków obrotowych, których przedmiot stanowi obrót towarami lub usługami powszechnie uznawanymi za bezproduktywne, zbytkowe i szkodliwe. Niemniej jednak, ze względu na cechy działalności hazardowej, odniesienie założeń tych teorii do podatków od gier wymaga rozpatrzenia szeregu kwestii, które mogą rodzić problemy aplikacyjne w praktyce gospodarczej i jako takie winny być brane pod uwagę w proce-

${ }^{53}$ Szerzej Whitman, Rizzo (2007): 428-429.

54 Ang. tax salience. Holmes Perkins (2014): 143.

55 Szerzej Becchetti, Bellucci, Rossetti (2018): 127-162.

${ }^{56} \mathrm{Na}$ określenie skutków społecznych podatków od gier używa się nawet terminu „odwrócony efekt Robin Hooda” (ang. reverse Robin Hood effect) Farrel (2008): 50. Szerzej Gandullia, Leporatti (2019): 565-590; Kohler (2016): 193-208; Hetzer, Peichl (2010): 31.

57 Szerzej Holmes Perkins (2014): 166-170. 
sie wyznaczania kierunków polityki hazardowej i podatkowej. Konfrontacja założeń powyższych teorii ze specyfiką hazardu prowadzi do następujacych wniosków.

Po pierwsze, bardziej dotkliwe opodatkowanie działalności gospodarczej polegającej na świadczeniu usług hazardowych, wynikające z przekonania, że popyt na tego rodzaju usługi wykazuje niska elastyczność cenowa, nie znajduje potwierdzenia w wynikach badań przeprowadzonych w tym zakresie w innych państwach. Poziom elastyczności cenowej popytu jest zróżnicowany w odniesieniu do poszczególnych form aktywności hazardowej, w ramach których istotne znaczenie ma również to, czy dane usługi są świadczone $\mathrm{w}$ formach naziemnych czy zdalnie. W związku z powyższym wszelkie zmiany mające wpływ na wysokość obciążenia funkcjonujacego w Polsce podatku od gier winny być poprzedzone przeprowadzeniem badań ekonomicznych dotyczących powyższej kwestii, w kontekście specyfiki krajowego rynku gier hazardowych. Analizy na tle danego rynku wymaga także problem efektu substytucyjnego, polegającego na zastępowaniu jednych rodzajów gier hazardowych innymi.

Po drugie, skonstruowanie podatku od gier, który spełniałby funkcję korekcyjna, wymaga oszacowania wielkości efektów zewnętrznych, a tym samym i kosztów społecznych hazardu, co stanowi kwestię niezwykle złożoną i kontrowersyjna. Bez wattpienia wprowadzenie wyższego opodatkowania w odniesieniu do niektórych form aktywności hazardowej nie powinno być wynikiem subiektywnego przekonania osób biorących udział w tworzeniu aktów prawnych. Zmiany przepisów mających na celu uzyskanie efektu korekcyjnego winny uwzględniać wyniki badań z zakresu nauk społecznych, dotyczaçcych między inymi potencjału uzależniającego poszczególnych gier.

Po trzecie, idea opodatkowania konsumpcji usług hazardowych w celu poprawy dobrobytu jednostek rodzi szereg problemów wynikających zarówno ze specyfiki cen usług hazardowych, jak i powszechnej dostępności gier oferowanych przez sieć Internet. W związku z powyższym wszelkie próby nadawania podatkowi od gier funkcji instrumentu kształtującego ludzkie zachowania powinny być poprzedzone badaniami z zakresu nauk społecznych. Szczególnie istotne wydaje się określenie struktury demograficznej graczy, odsetka i struktury demograficznej osób przejawiajacych zaburzenia uprawiania hazardu, motywacji graczy oraz wielkości środków angażowanych w gry, a także rozmiarów aktywności hazardowej realizowanej nielegalnie.

Michalina Duda-Hyz

Katolicki Uniwersytet Lubelski Jana Pawta II

dudami@kul.lublin.pl

https://orcid.org/0000-0001-7058-3481

Adams, M., Fiedler, I. (2018). Die sozialen Kosten von Glücksspielen, [w:] J. Gebhardt, S. Korte, Glücksspiel: Ökonomie, Recht, Sucht. Berlin-Boston.

Annacondia, F., Alonso, L.M. (2017). VAT and Gambling, [w:] R.F. van Brederode, R. Krever (eds.), VAT and Financial Services. Singapore. 
Barth, D., Der deutsche Glücksspiel- und Wettmarkt: Staatliche Einnahmen aus Steuern und Abgaben und deren Verwendung. <gluecksspiel.uni-hohenheim.de > Oekonomie > Gl...> [dostęp: 20.03.2020].

Becchetti, L., Bellucci, D., Rossetti, F. (2018). Gamblers, scratchers and their financial education. Economia Politica 35: 127-162.

Breen, R.B., Zimmerman, M. (2002). Rapid onset of pathological gambling in machine gamblers. Journal of Gambling Studies 18(1): 31-43.

Brüggemann, L. (2015). Die Besteuerung von Sportwetten im Rennwett- und Lotteriegesetz. Münster.

Campbell, C.S., Smith, G.J. (2003). Gambling in Canada - from vice to disease to responsibility: a negotiated history. Canadian Bulletin of Medical History 20(1): 121-149.

Chaloupka, F.J., Wakefield, M. (2001). Taxing tobacco: the impact of tobacco taxes on cigarette smoking and other tobacco use, [w:] R.L. Rabin, S.D. Sugarman (eds.), Regulating Tobacco. Oxford-New York: 39-66.

Clarke, H. (2002). Taxing sin: some economics of smoking, gambling and alcohol. The Melbourne Review 4(2): 30-36.

Clotfelter, Ch. (2005). Gambling taxes, [w:] S. Cnossen (ed.), Economics and Politics of Excise Taxation. Smoking, Drinking, Gambling, Polluting and Driving. Oxford: 82-114.

Collins, D., Lapsley, H. (2002). The social costs and benefits of gambling: an introduction to the economic issues. Journal of Gambling Studies 19(2): 123-148.

Congdon, W.J., Kling, J.R., Mullainathan, S. (2011). Policy and Choice. Public Finance through the Lens of Behavioral Economics. Washington, D.C.

Costes, J.M., Massin, S., Etiemble, J. (2014). Premičre évaluation de l'impact socio-économique des jeux d'argent et de hasard en France. Les notes de l'Observatoire des jeux 5: 1-5.

Cummings, J. (2010). Obesity and unhealthy consumption: the public policy case for placing a federal sin tax on sugary beverages. Seattle University Law Review 34: 273-298.

Diemer, G., Rodenberg, R.M. (2013). The economics of sports betting, [w:] L.V. Williams, D.S. Siegel (eds.), The Oxford Handbook of the Economics of Gambling. Oxford: 131-142.

Dowling, N., Smith, D., Thomas, T. (2005). Electronic gaming machines: are they the 'crack cocaine' of gambling? Addiction 100(1): 33-45.

Duda-Hyz, M. (2017). Loterie jako instrumenty pozyskiwania dochodów państwa w polskim prawie skarbowym w latach 1768-1871. Czasopismo Prawno-Historyczne 69(2): 89-109.

Eadington, W.R. (2003). Measuring costs from permitted gaming: concepts and categories in evaluating gambling's consequences. Journal of Gambling Studies 19(2): 185-213.

Farrel, L. (2008). When welfare economics and gambling studies collide, [w:] M. Viren (ed.), Gaming in the New Market Environment. Hampshire-New York.

Forest, D. (2012). Online gambling: an economics perspective, [w:] R.J. Williams, R.T. Wood, J. Parke (eds.), Routledge International Handbook of Internet Gambling. AbingtonNew York 2012: 29-45.

Forrest, D., Gulley, D., Simmons, R. (2010). The relationship between betting and lottery play. Economic Inquiry 48(1): 26-38.

Frecknall-Hughes, J. (2015). The Theory, Principles and Management of Taxation: An Introduction. New York.

Frey, J.H. (1992). Gambling on sport: policy issues. Journal of Gambling Studies 8(4): 351-360.

Gallet, C.A. (2015). Gambling demand: a meta-analysis of the price elasticity. The Journal of Gambling Business and Economics 9(1): 12-22.

Gandullia, L., Leporatti, L. (2019). Distributional effects of gambling taxes: empirical evidence from Italy. The Journal of Economic Inequality 17: 565-590.

Godłów-Legiędź, J. (2013). Ekonomia Behawioralna: od koncepcji racjonalności do wizji ustroju ekonomicznego. Ekonomia 4: 24-41.

Grądalski, F. (2006). System podatkowy w świetle teorii optymalnego opodatkowania. Warszawa.

Grinols, E.L. (2004). Gambling in America. Costs and Benefits. Cambridge.

Gu, X., Li, G. (2008) Why do various gaming markets adopt different tax rates? The Journal of Gambling Business and Economics 3(1): 1-20. 
Gu, X., Li, G. (2011). The general-equilibrium analysis of gaming taxes in different markets, [w:] N. Tsounis, A. Vlachvei, M. Gaetano, T. Monovasilis (eds.), International Conference on Applied Economics 2011. Perugia: 201-211.

$\mathrm{Gu}, \mathrm{X}$., Tam, P.S. (2014) The impacts of demand and supply elasticities on gambling tax choices. The Journal of Gambling Business and Economics 8(1): 53-71.

Harvey, P.J., Swayze, J.P., Walls, D.W. (2004). The revealed revenue effect of gambling taxation: logit analysis of better behaviour in a laboratory casino. International Journal of Management 21(4): 407-413.

Hetzer, N., Peichl, A. (2010). Steuerstrukturreform trotz leerer Kassen?! ifo Schnelldienst, ISSN 0018-974X, ifo Institut für Wirtschaftsforschung an der Universität München. München 63(1): 28-35.

Hannum R. C. (2013) A primer on the mathematics of gambling, [w:] L.V. Williams, D.S. Siegel (eds.), The Oxford Handbook of the Economics of Gambling. Oxford: 370-386.

Harvey, P.J., Swayze, J.P., Walls, W.D. (2004). The revealed revenue effects of gambling taxation: logit analysis of better behavior in a laboratory casino. International Journal of Management 21(4): 407-414.

Heady, Ch. (2007). Optymalne opodatkowanie jako wskazówka dla polityki podatkowej, [w:] M.P. Devereux (red.), Efektywność polityki podatkowej. Warszawa: 56-65.

Hoffer, A.J., Shughart II, W.E., Thomas, M.D. (2014). Sin taxes and sindustry. revenue, paternalism and political interest. The Independent Review 19(1): 47-61.

Holmes Perkins, R. (2014). Salience and sin: designating taxes in the new sin era. Brigham Young University Law Review 1: 143-184.

Kahle, H., Willer, I. (2019). Die steuerliche Behandlung von Glücksspielen - ein Überblick, [w:] A. Wöhr, M. Wuketich (eds.), Multidisziplinäre Betrachtung des vielschichtigen Phänomens Glücksspiel. Festschrift zu Ehren des 65. Geburtstags von Prof. Dr. Tilman Becker. Wiesbaden: $141-164$.

Kindt, J.W. (1998). Follow the money: gambling, ethics, and subpoenas. Annals of the American Academy of Political and Social Science 556: 85-97.

Kirchgässner, G. (2015). Soft paternalism, merit goods, and normative individualism. European Journal of Law and Economics. [Online] DOI 10.1007/s10657-015-9500-5.

Kohler, D. (2016). On the regressivity of gambling taxes in Switzerland. Swiss Journal of Economics and Statistics 152(3): 193-208.

Landers, J. (2008). What's the potential impact of casino tax increases on wagering handle: estimates of the price elasticity of demand for casino gaming. Economics Bulletin 8(6): 1-15.

Landes, X. (2015). Why taxing consumption? Justification, objections and social cooperation, [w:] H.P. Gaisbauer, G. Schweiger, C. Sedmak (eds.), Philosophical Explorations of Justice and Taxation. National Global Issues. Cham-Heidelberk-New York-Dordrecht-London: 101115.

Li G., Gu X., Wu, J. (2015). A trade based view on casino taxation: market conditions. Journal of Gambling Studies 31(2): 585-606.

Lorenzi, P. (2004). Sin taxes. Society 41(1): 59-65.

Lorenzi, P. (2006). The moral grounds of sin taxes. Society 44(1): 67-71.

Lorenzi, P. (2010). Taxing antisocial behavior for the common good. Society 47(4): 328-332.

Malawski, A. (2016). Teoria ekonomii czy ekonomia teoretyczna. Studia Metodologiczne 36: 175198.

Marfels, Ch. (1997). Casino gaming and VLT gaming: substitution effect or supplementation effect? Gaming Law Review 1(3): 333-340.

Markus, J.P. (2016). La fiscalité des jeux d'argent et de hasard, archétype d'une fiscalité rédemptrice? Droits 1(63): 79-96.

Mazurek-Chwiejczak, M. (2014). Podatki ekologiczne. Acta Universitatis Lodziensis. Folia Oeconomica 1(209): 59-69

McCarten, W.J., Stotsky, J. (1995). Excise taxes, [w:] P. Shome (ed.), Tax Policy Handbook. Washington D.C.: 100-103.

McGee, R.W. (2004). The Philosophy of Taxation and Public Finance. Boston-Dordrecht-London.

Meich, B.F. (2008). The power to destroy: the psychology of gaming taxation. Gaming Law Review and Economics 12(5): 458-465. 
Mizerski, D., Jolley, B., Mizerski, K. (2001). Disputing the "crack cocaine of gambling" label for electronic gaming machines, [w:] A. Blaszczynki (ed.), Culture and the Gambling Phenomenon. Proceedings of the 11th National Association for Gambling Studies Conference. Sydney: 276-283.

Nichols, M.W., Tosun, M.S. (2013). The elasticity of casino gambling, [w:] L.V. Williams, D.S. Siegel (eds.), The Oxford Handbook of the Economics of Gambling. Oxford: 37-51.

O’Donoghue, T., Rabin, M. (2006). Optimal sin taxes. Journal of Public Economics 90: $1825-1842$.

Ofiarski, Z. (2013). Opodatkowanie działalności w zakresie urządzania loterii - reminiscencje z okresu II Rzeczypospolitej oraz czasy współczesne, [w:] C. Kosikowski (red.), Prawo skarbowe i prawo finansowe. Szkoły i uczniowie. Księga dedykowana pamięci Profesora Jerzego Lubowickiego. Białystok: 141-157.

Philander, K.S. (2013). A normative analysis of gambling tax policy. UNLV Gaming Research \& Review Journal 17(2): 17-23.

Philander, K., Walker, D.M. (2012). William R. Eadington and the economics of gambling. UNLV Gaming Research \& Review Journal 16(2): 9-17.

Siu, R. (2011). A conceptual reconsideration of price issues with casino gaming. Gaming Law Review and Economics 15(5): 267-277.

Shackelford, D.A., Shaviro, D.N., Slemrod, J. (2012). Taxation and the financial sector, [w:] J.S. Alworth, G. Arachi (eds.), Taxation and the Financial Crisis. Oxford: 148-171.

Swacha-Lech, M. (2012). Zagadnienie krótkowzroczności jednostek w kontekście decyzji dotyczących gromadzenia oszczędności. Annales Universitatis Mariae Curie-Skłodowska. LublinPolonia. Sectio H 46(4): 795-802.

Thalheimer, R., Ali, M.M. (2003). The demand for casino gaming. Applied Economics 35(8): 907918.

Thomas, A.C., Sullivan, G.B., Allen, F.C.L. (2009). A theoretical model of EGN problem gambling: more than a cognitive escape. International Journal of Mental Health and Addiction 7: 97-107.

Thompson, W.N. (2010). Gambling taxes: the philosophy, the constitution and horizontal equity. Jeffrey S. Moorad Sports Law Journal 17(2): 1-32.

Thompson, W.N., Gazel, R., Rickman, D. (1997). Social and legal costs of compulsive gambling. Gaming Law Review 1(1): 81-89.

Tresch, R.W. (2008). Public Sector Economics. New York.

Vermeed, V., van der Ploeg, R., Timmer, J.W. (2009). Taxes and the Economy: A Survey on the Impact of Taxes on Growth, Employment, Investment, Consumption and the Environment. Northampton.

Vieweg, H.G. (2009). Der deutsche Glücks- und Gewinnspielmarkt im europäischen Kontext, ifo Schnelldienst, ISSN 0018-974X, ifo Institut für Wirtschaftsforschung an der Universität München. München 62(21): 13-21.

Walker, D.M. (2003). Methodological issues in the social costs of gambling studies. Journal of Gambling Studies 19(2): 149-181.

Walker, D.M. (2007a). The Economics of Casino Gambling. Berlin-Heidelberg-New York.

Walker, D.M. (2007b). Problems in quantifying the social costs and benefits of gambling. American Journal of Economics and Sociology 66(3): 609-646.

Walker, D. (2008). Ongoing challenges in research on the social cost of gambling, [w:] T. Coryn, C. Fijnaut, A. Litter (eds.), Economic Aspects of Gambling Regulation. EU and US Perspectives. Leiden-Boston: 13-30.

Walker, D.M. (2013). Overview of the economic and social impacts of gambling in the United States, [w:] L.V. Williams, D.S. Siegel (eds.), The Oxford Handbook of the Economics of Gambling. Oxford: 108-124.

Walker D.M., Hodges, C.D. (2018). Gambling taxes, [w:] A. Hoffer, T. Nesbit (eds.), For Your Own Good: Taxes, Paternalism, and Fiscal Discrimination in the Twenty-First Century. Arlington, VA: 361-374.

Walker D. M., Mandell, E. (2018). Ideas in behavioral economics related to gambling research. Paper presented at the 12th European Conference on Gambling Studies and Policy Issues Valletta, Malta 11-14 September 2018.

Whitman, D.G., Rizzo, M.J. (2007). Paternalist slopes. NYU Journal of Law \& Liberty 2: 411-443. 
Winkler, P., Bejdura, M., Csémy, L., Weissová, A. (2016). Social cost of gambling in the Czech Republic 2012. Journal of Gambling Studies. doi: 10.1007/s10899-016-9660-4

Zalega, T. (2015). Ekonomia behawioralna jako nowy nurt ekonomii - zarys problematyki. Studia i Materiały 1: 7-25.

\title{
THE LEGITIMATION OF GAMING TAX - DIRECTIONS IN THE SEARCH FOR THEORETICAL CONCEPTS
}

\begin{abstract}
$\mathrm{S} \mathrm{m} \mathrm{m}$ u a r y
The aim of the article is to identify economic theories which might be seen as justifying the existence of taxes on gambling as well as to confront the assumptions of these theories with the specific character of the gambling phenomenon. The subsequent sections of the article indicate the arguments in favour of additional taxation of gambling services resulting from the theory of optimal taxation, the theory of corrective tax, and the theories of behavioural economics. The article also presents the main controversies and application problems which arise from these theories in the context of the special character of gambling and gaming taxes.
\end{abstract}

Keywords: gambling; gaming tax; the theory of optimal taxation; the theory of corrective tax; theories of behavioural economics 
